\title{
THEORY OF PLANNED BEHAVIOR ON THE FACTORS ASSOCIATED WITH OF CLEAN AND HEALTHY BEHAVIOR IN IMOGIRI MARKET COMMUNITY
}

\author{
Hariza Adnani ${ }^{1}$, AA. Subiyanto ${ }^{2)}$, Diffah Hanim³), \\ Endang Sutisna Sulaeman ${ }^{2)}$ \\ ${ }^{1)}$ Graduate Programs in Health Promotion and Community Empowerment, \\ Sebelas Maret University \\ 2)Department of Public Health, Faculty of Medicine, Sebelas Maret University \\ 3)Masters Program in Nutrition, Sebelas Maret University
}

\begin{abstract}
Background: Achievement of Clean and Healthy Behavior (PHBS) in public places in Bantul Regency, Yogyakarta was only 54.55\% in 2015. This figure decreased as low as 50.91\% in 2016. The purpose of this study was to determine the factors associated with clean and healthy behavior in market community using Theory of Planned Behavior.

Subjects and Method: This was an analytic observational study using cross sectional design. This study was carried out in Imogiri traditional market, Bantul, Yogyakarta. A sample a 165 people from Imogiri market community (buyers, sellers, managers, parking attendants) were selected for this study by accidental sampling. The dependent variable was clean and healthy behaviors. The independent variables were attitude, subjective norm, and perceived behavior control. The data were collected by questionnaires and observation sheets. The data were analyzed using path analysis.

Results: Clean and healthy behavior was directly and positively influenced by positive attitude $(\mathrm{OR}=2.41, \mathrm{p}=0.016)$, favorable subjective norm ( $\mathrm{OR}=$ 2.37, $\mathrm{p}=0.018)$, strong perceived behavior control $(\mathrm{OR}=2.13 ;=0.033)$, and strong intention $(\mathrm{OR}=2.12 ; \mathrm{p}=0.034)$. Intention to have clean healthy behavior was positively associated with attitude $(\mathrm{OR}=2.17 ; \mathrm{p}=0.030)$, subjective norm $(\mathrm{OR}=2.52 ; \mathrm{p}=0.012)$, and perceived behavior control $(\mathrm{OR}=$ 2.55; $\mathrm{p}=0.011$ ).

Conclusion: Clean and healthy behavior is influence by positive attitude, favorable subjective norm, strong perceived behavior control, and strong intention.
\end{abstract}

Keywords: clean and healthy behavior, attitude, subjective norm, behavior, control, intention

Correspondence: Hariza Adnani. Graduate Programs in Health Promotion and Community Empowerment, Sebelas Maret University.

Email: adnani.hariza@yahoo.com 